\title{
A Study on Morphometric Dimensions of Human Fetal Spleen at Different Gestational Ages
}

\author{
D. Srivani ${ }^{1}$, P. Sofia ${ }^{2}$, J. Jayachandra Pillai ${ }^{3}$ \\ ${ }^{1}$ Assistant Professor, Department of Anatomy, SVIMS- Sri Padmavathi Medical college for women, Tirupathi, Andhra Pradesh, India, ${ }^{2}$ Assistant \\ Professor, Department of Anatomy,GMC [ RIMS], Kadapa, Andhra Pradesh, India, ${ }^{3}$ Professor \& HOD , Department of Anatomy, S V Medical College, \\ Tirupathi, Andhra Pradesh, India.
}

\section{Abstract}

\begin{abstract}
Introduction: The spleen is the largest hemolymphatic organ of the human body that plays a significant role in Hematopoiesis and immune phagocytosis. Recent studies have emphasized the importance of spleen as hematopoietic organ in fetal period, role in synthesis of immunoglobulins \& defense of human body against infections. A thorough knowledge of splenic morphometry and dimensions is vital in comprehending the development of spleen in fetal period. Aim: The aim of the study is to study detailed morphometric analysis human fetal splenic specimens of various gestational ages and compare the findings with earlier studies Subjects and Methods: The present study included 40 fetal cadaveric spleen and morphometric features i.e., length, breadth, width and weight of spleen were measured. Results: The average weight of the fetal spleen was $1.98 \mathrm{gm}$ and varied from 0.1 to $5.1 \mathrm{gm}$. The average length, breadth and width of spleen in prenatal group were $2.21 \mathrm{~cm}, 1.39 \mathrm{~cm}$ and $0.645 \mathrm{~cm}$ respectively. In the present study the average weight of the fetal spleen was $1.98 \mathrm{gm}$ and varied from 0.1 to $5.1 \mathrm{gm}$. There was statistically significant increase in splenic weight till 33 weeks. Conclusion: Knowledge of spleen size at different gestational ages will help in early detection and diagnosis of splenic anomalies, identifying congenital malformations, early diagnosis and prompt treatment of intrauterine infections.
\end{abstract}

Keywords: Spleen, Hematopoietic, Morphometric Analysis, Fetal.

Corresponding Author: Dr. P. Sofia, Assistant Professor, Department of Anatomy, GMC [RIMS], Kadapa, Andhra Pradesh, India. Email: sofiapeddity@gmail.com

Received: January 2020

Accepted: January 2020

\section{Introduction}

The spleen is a myriad of mysteries yet to be unravelled completely. Spleen is located in the left hypochondrium, and arises from mesenchymal proliferation between two leaves of dorsal mesogastrium during $5^{\text {th }}$ week of gestation. ${ }^{[1]}$ The spleen assumes its definitive morphological structure during the 3rd month and the size gradually increases during the fetal period. Sir Henry Gray in 1854 in the book "The structure and the use of spleen" reported the studies on 334 spleens of various animals determined the weight of the spleen before birth. ${ }^{[2,3,4]} \mathrm{He}$ compared the weight of spleen with that of body weight of fetus and found it to be 1 to 1400 at 5th month, 1to 700 at 7 th and 1 to 350 at 9th fetal month. ${ }^{[5,6]}$ Jian Hong You. ${ }^{[7]}$ (2014), Schmidt et al ${ }^{[8]}$ (2008) extensively studied the morphometric parameters of fetal spleen using 2D\&3D ultrasound. However there is limited research $^{[9-12]}$ regarding the cadaveric analysis of morphometric parameters of spleen in fetal period which warrants the purpose of this study.

\section{$\underline{\text { Aims \& Objectives }}$}

The aim is to study morphometric parameters of human fetal splenic specimens at various gestational ages and compare the parameters with the existing literature.

\section{Subjects and Methods}

The present study is a prospective type of study conducted in the department of Anatomy, S. V. Medical College, Tirupati Maternity Hospital, Tirupati. The ethical committee approval and consent of the relatives were obtained. Medically terminated fetuses of both sexes and relevant obstetric data were collected from Government Maternity Hospital, Tirupati which includes 40 dead aborted fetuses of both sexes ranging from 16 weeks of gestation to term.

In the department of anatomy, the collected fetuses were observed for congenital anomalies and the following fetal external parameters were measured by using weighing machine, measuring scale, thread and osteometric board. 1. Fetal weight 2. Bi-parietal diameter, 3. Head circumference 4. Crown-rump length 5. Crown-heel Length 6. Chest circumference. After recording the external parameters, they were preserved in $10 \%$ formalin. After one week of preservation, the abdomen was opened by using routine dissection method and the morphological observations were 
made insitu. Later spleen were removed by using routine dissection method and outer surface of fetal spleens were dried with blotting paper and then weighed by using digital weighing balance (SHIMADZU-ATY224-UNIbloc). The morphometric parameters measured were fetal weight, crown rump length, splenic weight, length, breadth and width. The collected data was subjected to statistical analysis by computing the mean of each parameter with respect to the gestational age-wise groups by using SPSS 20 version.

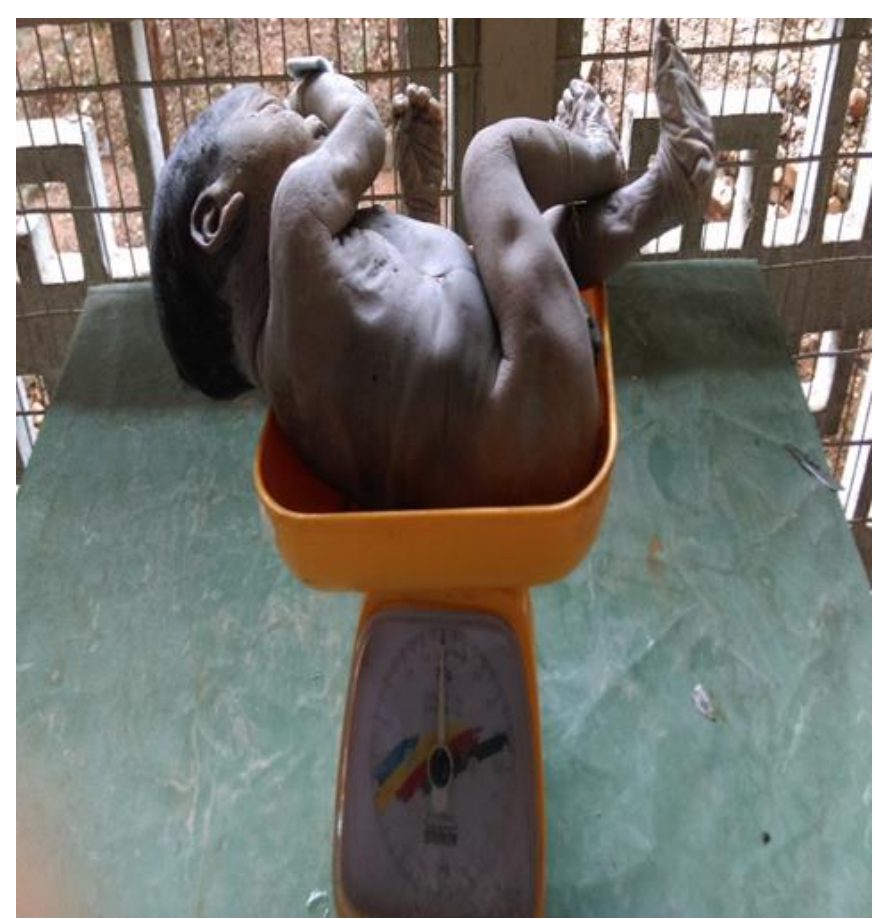

Figure 1: showing measurement of the Fetal weight with digital weighing balance (SHIMADZU-ATY224-UNIbloc)

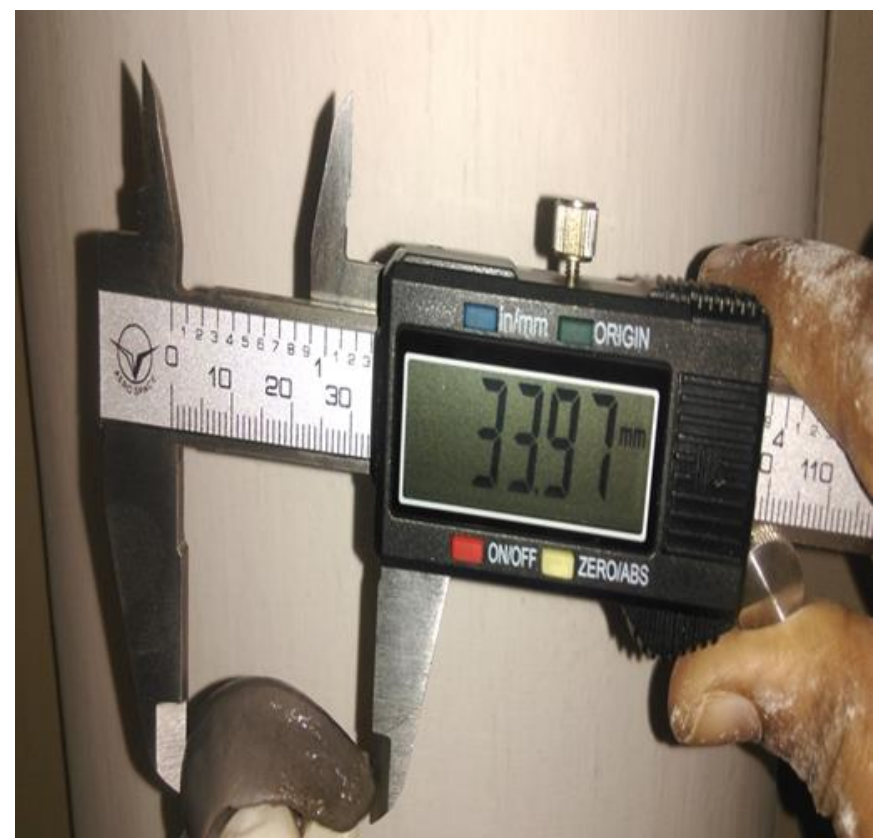

Figure 2: showing measurement of splenic length with digital Vernier calipers
Results

The fetal specimens were categorized into 5 groups i.e., 1620 weeks, 21- 24 weeks, 25-28 weeks, 29-32 weeks and 33 weeks to Term. The largest group was fetuses with gestational age 16-20 weeks with 10 specimens. The genderwise distribution was $57.5 \%$ and $42.5 \%$ for male and female groups respectively.

Table 1: Gestational age/ Gender wise distribution of prenatal group

\begin{tabular}{|l|l|l|l|l|}
\hline Group & $\begin{array}{l}\text { Gestational } \\
\text { age (weeks) }\end{array}$ & Male (\%) & Female (\%) & Total (\%) \\
\hline A & $16-20$ Weeks & $6(26)$ & $4(23.5)$ & $10(25)$ \\
\hline B & $\begin{array}{l}21-24 \\
\text { Weeks }\end{array}$ & $3(13)$ & $2(11.7)$ & $5(12.5)$ \\
\hline C & $25-28$ Weeks & $3(13)$ & $6(35.7)$ & $9(22.5)$ \\
\hline D & $29-32$ Weeks & $6(26)$ & $2(11.7)$ & $8(20)$ \\
\hline E & $33-$ Term & $5(22)$ & $3(17.6)$ & $8(20)$ \\
\hline & Total & $23(100 \%)$ & $17(100 \%)$ & $40(100)$ \\
\hline
\end{tabular}

The splenic weight is maximal in 29-32 weeks group with mean $3.33 \pm 1.01 \mathrm{gm}$ and a slight decrease thereafter till Term. The statistical analysis suggests that there is significant increase in fetal weight in relation to gestational age with maximal weight $3.38 \pm 1.01$ gm in $29-32$ weeks group. The maximal splenic weight is $5.1 \mathrm{gm}$ in a fetus of 30 weeks gestational age. The weight of the spleen ranged from $0.1 \mathrm{gm}$ to $5.1 \mathrm{gm}$. The average weight of the fetal spleen is $1.98 \pm 1.22 \mathrm{gm}$.

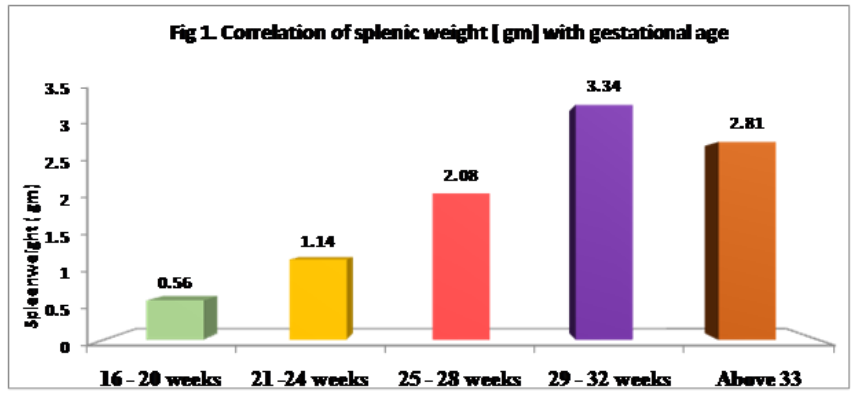

Graph 1: Correlation of gestational age for splenic length, breadth and width of prenatal group

Table 2: Summary of ANOVA and Duncan's Multiple Range Test (DMRT) by G. age

\begin{tabular}{|c|c|c|c|c|c|c|c|c|}
\hline Fetal & $\begin{array}{l}\text { G. } \\
\text { age }\end{array}$ & $\mathbf{N}$ & $\begin{array}{l}\text { Mea } \\
\text { n }\end{array}$ & $\begin{array}{l}\text { Std. } \\
\text { Deviati } \\
\text { on }\end{array}$ & $\begin{array}{l}\text { F- } \\
\text { value }\end{array}$ & $\begin{array}{l}\text { p- } \\
\text { valu } \\
\text { e }\end{array}$ & $\begin{array}{l}\text { Mi } \\
\text { n }\end{array}$ & $\begin{array}{l}\text { Ma } \\
\text { x }\end{array}$ \\
\hline \multirow[t]{4}{*}{$\begin{array}{l}\text { Lengt } \\
\mathrm{h}[\mathrm{cm}]\end{array}$} & $\begin{array}{l}16 \\
20 \\
\text { wee } \\
\text { ks }\end{array}$ & $\begin{array}{l}1 \\
0\end{array}$ & $\begin{array}{l}1.32 \\
0\end{array}$ & 0.2974 & \multirow[t]{4}{*}{$\begin{array}{l}23.646 \\
* *\end{array}$} & \multirow[t]{4}{*}{$\begin{array}{l}0.00 \\
0\end{array}$} & 0.9 & 1.7 \\
\hline & $\begin{array}{l}21 \\
24 \\
\text { wee } \\
\text { ks }\end{array}$ & 5 & $\begin{array}{l}1.94 \\
0\end{array}$ & 0.2510 & & & 1.7 & 2.3 \\
\hline & $\begin{array}{l}25 \\
28 \\
\text { wee } \\
\text { ks }\end{array}$ & 9 & $\begin{array}{l}2.45 \\
6\end{array}$ & 0.3321 & & & 1.8 & 2.8 \\
\hline & $\begin{array}{l}29- \\
32\end{array}$ & 8 & $\begin{array}{l}2.71 \\
3\end{array}$ & 0.4764 & & & 2.1 & 3.4 \\
\hline
\end{tabular}




\begin{tabular}{|c|c|c|c|c|c|c|c|c|}
\hline & \multicolumn{8}{|l|}{$\begin{array}{l}\text { wee } \\
\mathrm{ks}\end{array}$} \\
\hline & $\begin{array}{l}33- \\
\text { Ter } \\
\text { m }\end{array}$ & 8 & $\begin{array}{l}2.73 \\
8\end{array}$ & 0.4340 & & & 2.3 & 3.7 \\
\hline & $\begin{array}{l}\text { Tota } \\
1\end{array}$ & $\begin{array}{l}4 \\
0\end{array}$ & $\begin{array}{l}2.21 \\
5\end{array}$ & 0.6777 & & & 0.9 & 3.7 \\
\hline \multirow[t]{6}{*}{$\begin{array}{l}\text { Bread } \\
\text { th } \\
{[\mathrm{cm}]}\end{array}$} & $\begin{array}{l}16- \\
20 \\
\text { wee } \\
\text { ks }\end{array}$ & $\begin{array}{l}1 \\
0\end{array}$ & $\begin{array}{l}0.81 \\
0\end{array}$ & 0.2331 & \multirow[t]{6}{*}{$\begin{array}{l}22.017 \\
* *\end{array}$} & \multirow[t]{6}{*}{$\begin{array}{l}0.00 \\
0\end{array}$} & 0.4 & 1.2 \\
\hline & $\begin{array}{l}21- \\
24 \\
\text { wee } \\
\text { ks }\end{array}$ & 5 & $\begin{array}{l}1.24 \\
0\end{array}$ & 0.1949 & & & 1.1 & 1.5 \\
\hline & $\begin{array}{l}25- \\
28 \\
\text { wee } \\
\text { ks }\end{array}$ & 9 & $\begin{array}{l}1.50 \\
0\end{array}$ & 0.3500 & & & .8 & 1.9 \\
\hline & $\begin{array}{l}29- \\
32 \\
\text { wee } \\
\text { ks }\end{array}$ & 8 & $\begin{array}{l}1.81 \\
3\end{array}$ & 0.2696 & & & 1.5 & 2.1 \\
\hline & $\begin{array}{l}33- \\
\text { Ter } \\
\text { m }\end{array}$ & 8 & $\begin{array}{l}1.66 \\
2\end{array}$ & 0.1188 & & & 1.5 & 1.8 \\
\hline & $\begin{array}{l}\text { Tota } \\
1\end{array}$ & $\begin{array}{l}4 \\
0\end{array}$ & $\begin{array}{l}1.39 \\
0\end{array}$ & 0.4482 & & & 0.4 & 2.1 \\
\hline \multirow[t]{6}{*}{$\begin{array}{l}\text { Width } \\
{[\mathrm{cm}]}\end{array}$} & $\begin{array}{l}16- \\
20 \\
\text { wee } \\
\text { ks }\end{array}$ & $\begin{array}{l}1 \\
0\end{array}$ & $\begin{array}{l}0.41 \\
0\end{array}$ & 0.1912 & \multirow[t]{6}{*}{$2.593^{*}$} & \multirow[t]{6}{*}{$\begin{array}{l}0.05 \\
0\end{array}$} & 0.2 & 0.8 \\
\hline & $\begin{array}{l}21- \\
24 \\
\text { wee } \\
\text { ks }\end{array}$ & 5 & $\begin{array}{l}0.64 \\
0\end{array}$ & 0.1140 & & & 0.5 & 0.8 \\
\hline & $\begin{array}{l}25- \\
28 \\
\text { wee } \\
\text { ks }\end{array}$ & 9 & $\begin{array}{l}0.74 \\
4\end{array}$ & 0.3245 & & & 0.1 & 1.1 \\
\hline & $\begin{array}{l}29- \\
32 \\
\text { wee } \\
\text { ks }\end{array}$ & 8 & $\begin{array}{l}0.68 \\
8\end{array}$ & 0.3357 & & & 0.1 & 0.9 \\
\hline & $\begin{array}{l}33- \\
\text { Ter } \\
\mathrm{m}\end{array}$ & 8 & $\begin{array}{l}0.78 \\
8\end{array}$ & 0.3271 & & & 0.1 & $\begin{array}{l}01 . \\
2\end{array}$ \\
\hline & $\begin{array}{l}\text { Tota } \\
1\end{array}$ & $\begin{array}{l}4 \\
0\end{array}$ & $\begin{array}{l}0.64 \\
5\end{array}$ & 0.3029 & & & 0.1 & $\begin{array}{l}01 . \\
2\end{array}$ \\
\hline
\end{tabular}

The analysis shows morphometric parameters splenic weight, length and breadth steadily increased with gestational age and the difference is highly significant $(\mathrm{P}<0.05$, High $\mathrm{F}$ value $)$. The maximal splenic length is in 33 weeks to Term group with mean $2.7 \mathrm{~cm} \pm 0.47 \mathrm{~cm}$ with gradual and significant increase with gestational age. The average splenic length is $2.21 \pm 0.67 \mathrm{~cm}$ and varied from 0.9 to $3.7 \mathrm{~cm}$.

The analysis by gestational age for splenic breadth showed a gradual and significant increase with gestational age up to 33 weeks reaching maximum in 29-32 week group (mean breadth $1.81 \pm 0.269 \mathrm{~cm})$ and a slight decrease there afterwards. The average splenic breadth is $1.39 \pm 0.44 \mathrm{~cm}$. The analysis of splenic width with gestational age showed statistically insignificant association with gestational age. The average splenic width is $0.645 \pm 0.302 \mathrm{~cm}$ and the maximal width is in 33 weeks to Term. The splenic width varied from 0.1 to $1.2 \mathrm{~cm}$.
Figure 2 :Morphometric parameters of the prenatal group by gender

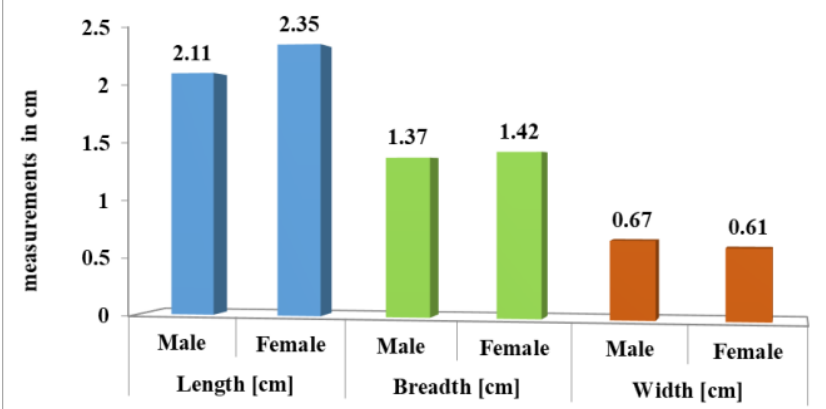

Graph 1: Correlation of gestational age for splenic length, breadth and width of prenatal group

The mean splenic length, breadth and width followed the same pattern as splenic weight in relation to gender without any statistically significant difference in male and female groups ( $\mathrm{P}$ values $0.2,0.7$ and 0.55 respectively).The Karl Pearson coefficient of correlation analysis showed a positive correlation between the fetal weight and the morphometric parameters like splenic weight, length, breadth and width with maximal positive correlation between the fetal weight and the splenic length (Pearson coefficient 0.814) and least positive correlation between fetal weight and splenic width. In the present study the correlation of weight of spleen with that of body weight of fetus found to be 1 to 707 at 16-20 wks, 1 to 763 at $21-24$ wks, 1 to 620 at $25-28$ wks, 1 to 543 at $29-32$ wks and 1 to 769 at 33 wks to Term

Table 3: Ratio between fetal weight and splenic weight in different groups

\begin{tabular}{|l|l|l|l|}
\hline $\begin{array}{l}\text { Gestational age } \\
\text { (wks.) }\end{array}$ & $\begin{array}{l}\text { Average fetal } \\
\text { Weight } \\
\text { (gm) }\end{array}$ & $\begin{array}{l}\text { Average } \\
\text { splenic } \\
\text { Weight }(\mathbf{g m})\end{array}$ & $\begin{array}{l}\text { Ratio } \\
\text { between fetal } \\
\text { and spleen } \\
\text { weight } \mathbf{( \% )}\end{array}$ \\
\hline $16-20$ weeks & 396 & 0.560 & 0.14 \\
\hline $21-24$ weeks & 870 & 1.140 & 0.13 \\
\hline $25-28$ weeks & 1290 & 2.078 & 0.16 \\
\hline $29-32$ weeks & 1809.5 & 3.338 & 0.18 \\
\hline $33-$ Term & 2162.5 & 2.812 & 0.12 \\
\hline
\end{tabular}

\section{Discussion}

In the present study the average weight of the prenatal spleen was $1.98 \mathrm{gm}$. The splenic weight ranged from $0.1 \mathrm{gm}$ to $5.1 \mathrm{gm}$ which gradually increased with gestational age significantly till 32 weeks. The findings of morphometric parameters in the present study were in accordance with the observations of 2D \& 3D ultrasound guided measurements in fetuses by Jian-Hong You et al ${ }^{[7]}$ (2014), Toshiyuki Hata et al ${ }^{[13]}(2007)$, Schmidt et al $(1985)^{[8]}$.

The findings regarding the weight of the spleen in relation to gestational age were in agreement with the observations of Gruenwald P \&Minh HN (1960) ${ }^{[6]}$ and John G Archie et $\mathrm{al}^{[14]}$ (2006) in prenatal autopsies and with the descriptions of Sir Henry Gray (1854) ${ }^{[2]}$ and Potter (1961) $)^{[15]}$ till 32 weeks of gestation and not in agreement afterwards.

The weight of the spleen at term was reported as $13 \mathrm{gm}(210$ grains) by Sir Henry Gray (1854) and 11 gm by potter (1961) which was not observed in the present study which were more than the average observed in the present study. 
Table 4: Gestational age with splenic weight

\begin{tabular}{|l|l|l|l|l|}
\hline G. age & $\begin{array}{l}\text { Present } \\
\text { study } \\
\text { Mean } \\
\text { Splenic } \\
\text { weight }\end{array}$ & $\begin{array}{l}\text { Sir Henry } \\
\text { Gray[2](1854) }\end{array}$ & $\begin{array}{l}\text { Gruenwald P } \\
\text { \& Minh } \\
\text { HN[6](1960) }\end{array}$ & $\begin{array}{l}\text { John G } \\
\text { Archie } \\
\text { et al[14] } \\
(2006)\end{array}$ \\
\hline $16-20$ weeks & $0.560 \mathrm{gm}$ & $0.32 \mathrm{gm}$ & - & $0.23 \mathrm{gm}$ \\
\hline $21-24$ weeks & 1.140 & $1.16 \mathrm{gm}$ & $1.7 \mathrm{gm}$ & $0.71 \mathrm{gm}$ \\
\hline $\begin{array}{l}25-28 \\
\text { weeks }\end{array}$ & 2.078 & $1.94 \mathrm{gm}$ & $2.6 \mathrm{gm}$ & $1.63 \mathrm{gm}$ \\
\hline $\begin{array}{l}29-32 \\
\text { weeks }\end{array}$ & 3.338 & $3.88 \mathrm{gm}$ & $4.1 \mathrm{gm}$ & $3.5 \mathrm{gm}$ \\
\hline $\begin{array}{l}33 \mathrm{wks}- \\
\text { Term }\end{array}$ & 2.812 & $4.5 \mathrm{gm}$ & $6.7 \mathrm{gm}$ & - \\
\hline
\end{tabular}

Table 5: Gestational age with splenic length

\begin{tabular}{|c|c|c|c|c|c|}
\hline G. age & $\begin{array}{l}\text { Present } \\
\text { study } \\
\text { Splenic } \\
\text { length } \\
\text { (cm) }\end{array}$ & $\begin{array}{l}\text { Jian- } \\
\text { Hong } \\
\text { You } \\
\text { et al }^{[7]} \\
(2014)\end{array}$ & $\begin{array}{l}\text { Schmidt } \\
\text { et al }^{[8]} \\
(\mathbf{1 9 8 5})\end{array}$ & $\begin{array}{l}\text { Shaik } \\
\text { Hussain } \\
\text { et } \text { al }^{[16]} \\
(\mathbf{2 0 1 3})\end{array}$ & $\begin{array}{l}\text { Toshiyuki } \\
\text { Hata et } \\
\text { al }^{[13,17]} \\
(2007)\end{array}$ \\
\hline $\begin{array}{l}\text { 16- } 20 \\
\text { weeks }\end{array}$ & $1.32 \mathrm{~cm}$ & $\begin{array}{l}1.79 \\
\mathrm{~cm}\end{array}$ & $1.7 \mathrm{~cm}$ & $1.7 \mathrm{~cm}$ & $1.5 \mathrm{~cm}$ \\
\hline $\begin{array}{l}21-24 \\
\text { weeks }\end{array}$ & $1.94 \mathrm{~cm}$ & $\begin{array}{l}2.15 \\
\mathrm{~cm}\end{array}$ & $2.08 \mathrm{~cm}$ & - & - \\
\hline $\begin{array}{l}25-28 \\
\text { weeks }\end{array}$ & $2.45 \mathrm{~cm}$ & $\begin{array}{l}2.68 \\
\mathrm{~cm}\end{array}$ & $2.8 \mathrm{~cm}$ & $2.5 \mathrm{~cm}$ & - \\
\hline $\begin{array}{l}29-32 \\
\text { weeks }\end{array}$ & $2.71 \mathrm{~cm}$ & $\begin{array}{l}2.91 \\
\mathrm{~cm}\end{array}$ & $3.3 \mathrm{~cm}$ & - & - \\
\hline $\begin{array}{l}33 \text { wks - } \\
\text { Term }\end{array}$ & $2.73 \mathrm{~cm}$ & $\begin{array}{l}3.26 \\
\mathrm{~cm}\end{array}$ & $5.1 \mathrm{~cm}$ & $2.67 \mathrm{~cm}$ & $4 \mathrm{~cm}$ \\
\hline
\end{tabular}

In the present study splenic length steadily increased with gestational age and the difference was highly significant $(\mathrm{P}<0.05)$ and average was $2.21 \mathrm{~cm}$. These findings were in agreement with the study on aborted fetuses by Shaik Hussain et al ${ }^{[16]}$ (2013). The fetal splenic length at $5^{\text {th }}$ month was $1.32 \mathrm{~cm}$ and term was $2.73 \mathrm{~cm}$, which was in agreement with the findings of Toshiyuki Hata et $\mathrm{a}^{[13,17]}$ (2007).

The present study showed a gradual and significant increase ( $\mathrm{P}$ value $<0.05$ ) of splenic breadth with gestational age up to 33 weeks reaching maximum in 29-32 week group and a slight decrease thereafter and average was $1.39 \mathrm{~cm}$ which was in agreement with the descriptions of Shaik Hussain et $\mathrm{al}^{[16]}$ (2013), Jian-Hong You et al ${ }^{[7]}(2014)$, Toshiyuki Hata et $\mathrm{al}^{[13,17]}$ (2007), Schmidt et al ${ }^{[8]}$ (1985)

In the present study the average splenic width was $0.645 \mathrm{~cm}$ and correlation of splenic width with gestational age showed statistically insignificant and the maximal width is in 33 weeks to Term group .These findings were in agreement with the observations of Jian-Hong You et al (2014) ${ }^{[7]}$ till 28 weeks and not in agreement afterwards.

Splenic volume calculated from the regression formula 1.83 $\mathrm{x}$ length $\mathrm{x}$ breadth $\mathrm{x}$ width by Ellen M. Yetter et $\mathrm{al}^{[10]}$.

\begin{tabular}{|c|c|c|c|c|}
\hline G.age & $\begin{array}{l}\text { Present } \\
\text { study }\end{array}$ & 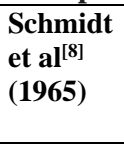 & $\begin{array}{l}\text { Latini et } \\
\text { al }^{[9]} \\
(2004)\end{array}$ & $\begin{array}{l}\text { Toshiyuki } \\
\text { Hata } \\
\text { et al }{ }^{[13,17]} \\
(2007)\end{array}$ \\
\hline 16- 20 weeks & $1.83 \mathrm{cc}$ & - & - & - \\
\hline $21-24$ weeks & $2.43 \mathrm{cc}$ & 2.2 & 3 & - \\
\hline $25-28$ weeks & $2.86 \mathrm{cc}$ & 3.4 & - & $2.2 \mathrm{cc}$ \\
\hline 29 - 32 weeks & $4.81 \mathrm{cc}$ & 5.7 & 8 & $6.2 \mathrm{cc}$ \\
\hline 33 wks -term & $8.77 \mathrm{cc}$ & 10.1 & 15 & $9.3 \mathrm{cc}$ \\
\hline
\end{tabular}

The present study showed a gradual and significant increase of splenic volume with gestational age upto till term which correlated with the findings of Schmidt et a ${ }^{[8]}$ (1965) and Toshiyuki Hata et $\mathrm{al}^{[13,17]}$ (2007) but differed with the findings of Latini et al. ${ }^{[9]}$

However, the slight differences in the morphometric parameters with respect to previous studies may be attributed to the genetic factors, geographical conditions, maternal feeding habits, fetal care and the socioeconomic status of the population where these studies were done.

\section{Conclusion}

The parameters observed by our study regarding morphometric dimensions at various gestational ages of fetal spleen provide useful information to sonologist to assess the stages of growth with measurement of the spleen in utero. Antenatal detection of splenomegaly is helpful in identifying hemolytic anemia, congestive heart failure, various metabolic disorders and even leukemias in fetus. Prenatal detection of splenic abnormalities is a valuable tool in diagnosing developmental anomalies in utero, early diagnosis of intrauterine infections and can be used as a surrogate marker of fetal development.

\section{References}

1. Susan Standring. Gray's Anatomy, The Anatomical Basis of Clinical Practice. 40th ed. Elsevier Churchill Livingstone Publications; 2008: 70:1187-1190

2. Gray H. On the Structure and Use of the Spleen. London, John W. Parker and Son, 1854, pp. 1-53

3. Mebius RE, Kraal G. Structure and function of the spleen. Nat Rev Immunol. 2005 Aug; 5(8):606-16.

4. Srisupundit K, Piyamongkol W, Tongprasert F, et al. Reference range of fetal splenic circumference from 14 to 40 weeks of gestation. Arch Gynecol Obstet 2011;283(3):449-53.

5. Üngör B, Malas MA, Sulak O et al 2007 Development of spleen during fetal period. Surg Radiol Anat 29:543-50.

6. Gruenwald P, Minh HN. Evaluation of body and organ weights in perinatal pathology I. Normal standards derived from autopsies. Am J Clin Pathol 1960; 34: 247-253.

7. Jian-Hong Y. Reference ranges of fetal spleen biometric parameters and volume assessed by three-dimensional ultrasound and their applicability in spleen malformations. Prenatal Diag 2014;34:1-9.

8. Schmidt W, Yarkoni S, Jeanty $\mathrm{P}$, et al. Sonographic measurements of the fetal spleen: clinical implications. J Ultrasound Med 1985;4(12):667-72.

9. Latini G, De Mitri B, Del Vecchio A, Chitano G, De Felice C, Zetterström R. Foetal growth of kidneys, liver and spleen in intrauterine growth restriction: 'programming' causing 'metabolic syndrome' in adult age. Acta Paediatr 2004; 93: 1635-1639.

10. Yetter EM, Acosta KB, Olson MC, Blundell K. Estimating splenic volume: sonographic measurements correlated with helical CT determination. AJR Am J Roentgenol 2003;181:1615-1620

11. Hansen K, Sung CJ, Huang C, Pinar H, Singer DB, Oyer CE, Reference values for second trimester fetal and neonatal organ weights and measurements. Pediatr. Dev. Pathol. 2003;6:160-167.

12. Rodrigues AJ, Rodrigues CJ, Germano MA, Rasera I, Cerri GG. Sonographic assessment of normal spleen volume. Clin Anat $1995 ; 8: 252-255$

13. Hata $\mathrm{T}$, Aoki $\mathrm{S}$, Takamori $\mathrm{H}$, Hata $\mathrm{K}$, Murao $\mathrm{F}$, Kitao $\mathrm{M}$. Ultrasonographic in utero identification and measurement of the normal fetal spleen. Gynecol Obstet Invest 1987; 23: 124-128.

14. Archie JG. Quantitative Standards for Fetal and Neonatal 


\section{Srivani et al; Marphametric Dimensians of Fuman Fetal Spleen}

Autopsy. Am J Clin Pathol 2006; 126:256-265.

15. Potter EL. Pathology of Foetal Neonatal Anatomy. (1961), pp. $415-420$

16. Saheb SK. Morphological and Morphometric Study of Human
Foetal Spleen. Int J Anat Res 2014, 2(1):234-38.

17. Aoki S, Hata T, Kitao M. Ultrasonographic assessment of fetal and neonatal spleen. Am J Perinatol 1992; 9: 361-367.

Copyright: () the author(s), 2020. It is an open-access article distributed under the terms of the Creative Commons Attribution License (CC BY 4.0), which permits authors to retain ownership of the copyright for their content, and allow anyone to download, reuse, reprint, modify, distribute and/or copy the content as long as the original authors and source are cited.

How to cite this article: Srivani D, Sofia P, Pillai JJ. A Study on Morphometric Dimensions of Human Fetal Spleen at Different Gestational Ages. Acad. Anat. Int. 2020;6(1):10-14.

DOI: dx.doi.org/10.21276/aanat.2020.6.1.3 